\title{
A Paradigm Shift of Learning in Maritime Education amidst COVID-19 Pandemic
}

\author{
Gregorio S. Ochavillo ${ }^{1}$ \\ ${ }^{1}$ College Dean, College of Maritime Education, Palompon Institute of Technology, Palompon, Leyte, Philippines \\ Correspondence: Gregorio S. Ochavillo, Palompon Institute of Technology, Palompon, Leyte, Philippines.
}

Received: August 8, 2020

Accepted: September 11, 2020

Online Published: September 18, 2020

doi:10.5430/ijhe.v9n6p164

URL: https://doi.org/10.5430/ijhe.v9n6p164

\begin{abstract}
This paper aimed to determine the maritime students' readiness to cope with the abrupt paradigm shift from face-to-face to online learning for the first time in maritime education amidst the outbreak of the COVID-19 pandemic. It utilized a descriptive-normative approach where incoming 2nd year and 3rd-year maritime students were the respondents. Data gathering was online using a survey questionnaire in Google Forms. Participation was limited while everybody was under the community lockdowns for safety and health reasons. Internet connectivity was also a limiting factor. Statistical tools used were frequency count and percentage.

The study showed a majority or 7 of 10 among maritime students were not ready to cope with the paradigm shift on the basis of not having a computer of their own for school works; no internet connectivity at home; no access to internet shops; and personal wellbeing. Almost 3 of 5 of them preferred face-to-face learning.

A catch-up framework in maritime education was proposed to address problems relative to the opening of SY 2020-2021 by delaying it to January 2021. Lecture-based subjects were scheduled in the early part while laboratory requiring the use of simulator in the later part of every curriculum year. This will ensure the acquisition of competencies through actual engagement in simulator operation among students. The catch-up framework gives the maritime students opportunities to graduate within the prescribed period of their curriculum despite the outbreak of COVID-19. The government, school authorities, parents, and faculty members also benefit from this framework once adapted.
\end{abstract}

Keywords: blended learning, face-to-face learning, COVID-19 pandemic, maritime education, online learning, paradigm shift

\section{Introduction}

Education caters to inclusive opportunities grounded on the principle that everyone has equal access to quality education, leaving no one behind. However, the present educational landscape in the Philippines has abruptly changed to a phenomenal level amidst the outbreak of the COVID-19 pandemic. The paradigm shift from face-to-face learning to online learning is too risky to happen for the first time without in-depth planning and preparations posing widespread failures.

Along this line, the World Health Organization (WHO) has declared the COVID-19 as a global pandemic on 11 March 2020, suddenly disrupting social and economic activities around the world (Association of Southeast Asian Nations [ASEAN], 2020). Everybody joined in concerted efforts to contain further transmission of the coronavirus, reducing its impacts and following health protocols (De Stefani, Bruno, Mutinelli, \& Gracco, 2020; United Nations International Children's Emergency Fund [UNICEF], 2020). Governments have imposed community lockdowns measures in order to control the spread of the coronavirus (ASEAN, 2020; National Economic Development Authority [NEDA], 2020). The Philippines also has implemented calibrated community lockdowns in the major island of Luzon. Other provinces around the country have implemented similar measures.

An estimate by the United Nations Department of Economic and Social Affairs (UN DESA) revealed that COVID-19 might cause the global economy to shrink by nearly 1 percent by the end of 2020 . The economic recession has affected higher education institutions (HEIs) in many ways (United Nations Academic Impact [UNAI], 2020).

The Philippines is no exception. Employment opportunities for new graduates in 2020 were low. Schools were unable to collect tuition fees as parents were in a survival mode. As the National Economic Development Authority, 
2020 (NEDA, 2020) has reported, the Philippines will absorb a cumulative loss due to the simultaneous adverse effect of supply and demand of PHP428.7 to PHP1,355.6 billion equivalent to 2.1 to 6.6 percent of nominal GDP in 2020. If unmitigated by the government, this would bring down the country's real GDP growth to -0.6 to 4.3 percent in 2020 .

Consequently, one of the heavily affected sectors was the educational system around the world. Over 1.2 billion students worldwide were suddenly out in school (World Economic Forum [WEF], 2020; UNAI, 2020). In the Philippines, classes suddenly ended, as schools have to close abruptly for public health reasons, including in maritime education. Maritime students went home to their respective provinces or municipalities for their safety.

In line with this, Figure 1 shows the model with the maritime higher education institutions interacting with the teaching staff on one sphere and the maritime students with their parents on the other sphere. At the center of the two overlapping spheres is the paradigm shift of learning. The paradigm shift characterizes by the sudden transition from face-to-face to online learning due to the outbreak of the COVID-19 pandemic. The government provides a foundation of the two spheres in terms of directions, policies, financial and structural aspects in shifting to the new educational landscape.

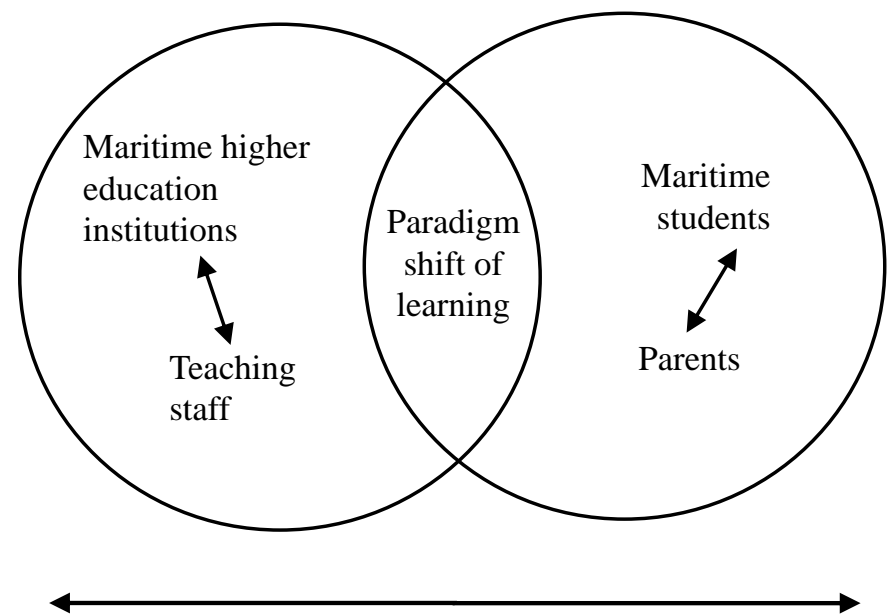

Figure 1. Model of paradigm shift of learning in maritime education

The use of online learning is practically reshaping the landscape in the country's maritime education as COVID-19 continues a threat to everybody. In maritime education, it is a new model in the delivery of learning. As pointed out by Barber, Donelly and Rizvi (2013), learning content becomes freely available in online learning. The COVID-19 has triggered this abrupt paradigm shift in maritime education affecting all elements in the model in Figure 1. Thus, the two sets of elements inside the spheres play very important roles in the successful provisions of maritime education at all times. When one set of elements in the model cannot function, the other one would become meaningless. One cannot function without the other.

Inasmuch as the COVID-19 cases in the Philippines continue spiking, concerns on how would if maritime students and their parents were not ready for the paradigm shift? Maritime students were dependent on their parents' financial support to continue pursuing their studies. They are the element in the model that the government nor school administration cannot manipulate towards the adaptation of the paradigm shift. Will MHEIs proceed with the paradigm shift even if students were not ready for it, leaving them behind? However, the call to shift abruptly into it is so dynamic that almost everybody in the academe was heading into the same direction not knowing what the future looks like. What lies ahead in the new educational landscape in maritime education? Thus, the conduct of this study.

Utilizing a descriptive-normative approach, the study primarily aimed to determine the readiness of the maritime students of a national government-funded maritime school in the Philippines in coping with an abrupt paradigm shift to online learning amidst the outbreak of the coronavirus COVID-19 pandemic. Also elicited were concerns of the students as regards to the challenges for SY 2020-2021 grounded on the economic difficulties all of them have withstood. Specific questions offered for this study were:

1. What were the income sources of the maritime students' parents?

2. What intent do the maritime students have in pursuing their studies through online learning in the school 
year 2020-2021?

3. Were the maritime students ready to cope with the paradigm shift, in terms of:

3.1 personal wellbeing,

3.2 ownership of a computer or laptop,

3.3 internet connection at home, and

3.4 access to internet-shop?

4. What delivery of learning is preferred most by maritime students?

5. What were the concerns of the maritime students in shifting to online learning?

6. What alternative action the study can propose?

Findings in this study provided clear direction and various possible scenarios awaiting ahead. Without this study, schools could be moving forward with uncertainties.

\section{Method}

The study has utilized the descriptive-normative survey design (Zulueta \& Costales, 2003). This study was limited only for the maritime students of a national government-funded MHEI in Region 8 (Eastern Visayas), Philippines. This maritime school is having an international partnership with a foreign shipowners association since 2001. It has since been providing the association with competent merchant officers and cadets for their crew requirements onboard oceangoing ships.

The locale was at the MHEI's main campus with the respondents from the provinces within Region 8 (Eastern Visayas), as follows: Leyte (74.17\%), Southern Leyte (6.27\%), Northern Samar (0.37\%), Eastern Samar (4.43\%), Western Samar (5.54\%), and from other provinces (9.22\%). The region, according to NEDA (2020), has a poverty incidence of 30.9 compared to 16.6 for national, and subsistence incidence of 10.0 higher than the 5.2 for national, among populations in 2018. This MHEI was no longer collecting tuition and miscellaneous fees from students by virtue of the law embodied in the Republic Act 10931.

The respondents of this study were the MHEI's incoming 2nd-year and 3rd-year maritime students for SY 2020-2021. Not considered respondents were the incoming 1st-year maritime students because they are not yet officially enrolled and the 4th-year maritime students because they will be having their 1-year onboard training aboard seagoing ships of more than 500 gross tonnages.

Population size was 444 considered from the 2nd semester of SY 2019-2020 enrollment among 1st-year and 2nd-year maritime students. According to Dessel (2013), a response rate of $20 \%$ is a good response rate, while $30 \%$ is considered really good in an online survey. A total of 271 or $61.03 \%$ have responded to the study.

Created using the Google Forms for a web-based survey tool (Raju \& Harinarayana, 2016), the survey questionnaire was tested and re-tested with the help of maritime instructors before it was finalized and made available online. The questionnaire elicited responses as regard to readiness in coping with the abrupt paradigm shift. In addition, their intention in coming back to school in the SY 2020-2021 and concerns that bother them relative to the abrupt shifting. Also elicited in the survey were profile information, e.g. year level, gender, municipality, and the province of residence. However, the responses gathered were not included in this report.

As regards the income sources of the parents, the groups considered in the study are as follows:

1) Government $=$ those working with agencies of the national government and local government units;

2) Private $=$ those working with private companies including domestic seafarer;

3) Overseas Filipino Workers $(\mathrm{OFW})=$ those working overseas, either sea or land-based; and

4) Informal = those without a regular income to include farmer, driver, fisherman, sari-sari store (a small store in the neighborhood), tuba (coconut wine) gatherer, carpenter, self-employed, shop helper, gasoline helper, construction worker, food vendor, pensioner, and no work at all, among others.

With respect to the maritime students intending to pursue their studies by means of online learning in the upcoming SY 2020-2021, options 'No' and 'Unsure' were responses considered uncertainties in this study. Thus, combining the responses attributed to the two options. Uncertainty can affect decision-making (Sniazhko, 2019), uncertain in the analysis to describe or foresee a phenomenon due to the intrinsic variability of the phenomenon itself (Zio \& Pedroni, 2013) and COVID induced uncertainties (Baker, Bloom, Davis, \& Terry, 2020) like what is happening in maritime 
education.

The gathering of data started on June 9, 2020, until June 23, 2020, through online. Another way was the use of e-mail.

Statistical tools used were frequency count and percentage. The maritime students' population scenario for SY 2020-2021 was also determined. Baseline data was the population of 1st-year and 2nd-year maritime students in the SY 2019-2020.

This study proposes adapting the framework for the catch-up in maritime education (Figure 3) for school years 2020-2021, 2021-2022, and 2022-2023. Developed through out-of-the-box thinking, the framework addresses problems caused by the COVID-19 pandemic. Other maritime and non-maritime schools can use this framework in the event they decide to delay the start of SY 2020-2021 to January 2021. This further ensure the acquisition of competencies among maritime students especially for subjects with laboratory requiring the use of simulator equipment. Schedule subjects with laboratory component for offering in the later part of the curriculum waiting that everything return to normal. This also allows maritime students an opportunity to have actual learning experiences in the operations of simulators. Overall, this catch-up framework allows every student inclusive opportunity to quality education despite the outbreak of the COVID-19 pandemic.

\section{Related Literature}

As highlighted in UNAI (2020), the coronavirus has affected employment, education, and other areas of the world economy. This includes the emotional well-being of citizens. Similarly, the world has witnessed a widespread disruption in the deliveries of education and training needs of societies (Ahmed, Allaf \& Elghazaly, 2020; Goh, 2016; Goh \& Sandars, 2020; Murphy, 2020; UNAI, 2020; UNICEF, 2020).

Along this line, distance learning, blended learning, online learning, and the effective use and increased awareness of technologies were among options in the innovative ways of delivering education as a result of the pandemic (Goh \& Sandars, 2020; Iwai, 2020; Jhaveri, Schrier \& Joseph, 2013; Podik, 2017; UNAI, 2020). These were products of a strong technological force a long time before but are now influencing the education landscape as impacted by the COVID-19 pandemic (Hilmi, 2016).

Distance learning is learning away from the institution. Students work with the learning resources materials that can be paper-based, on videotape, available on broadcast TV, or accessed online. While blended learning is a combination of face-to-face and online learning (Fry, Ketteridge \& Marshall, 2015). On the other hand, face-to-face instruction includes both traditional and web-facilitated courses where zero to $29 \%$ of course contents is online (Allen et al., 2013).

As regard to online learning, it enables students to access information in an inquiry-based model and enhances interaction with content for better understanding (Ramsden, 2003). Online courses are those in which at least $80 \%$ of the course content is online (Allen et al., 2013). In addition, Brenton, in Fry et al. (2015) indicated that online medium now supports a range of human interactions; creates conditions for engaging educational experiences in a way not possible before. Thus, the mode of synchronous and asynchronous (Biggs \& Tang, 2011). Whereas, Pike, in Fry et al. (2015) highlighted that online learning allows student flexibility in terms of time and place in which they learn.

Moreover, there is also an extended reality (XR), to include virtual reality (VR) and augmented reality (AR) promising a model of education that is dynamic, accessible, and adaptable to student needs. These give the trainees repeatable access to life-like experiences without risk, and gives evaluators a tool to benchmark and customize the learner experience (Zweifach \& Triola, 2019).

As schools across the country roll out their distance learning plans, questions on how to implement them remain the concern (Kajeet, 2020). How to overcome the challenges of online learning? The unplanned and abrupt shift to online learning - with no training, insufficient bandwidth, and little preparation - will result in a poor user experience that is unconducive to sustained growth. Some students without reliable internet access and/or technology struggle to participate in digital learning. This was an observed gap across countries and between income brackets within countries (WEF, 2020).

Today, public higher education faces increasing challenges, including changing models of educational delivery (Sukhwant, 2017) and making use of new possibilities in ICT innovations (Delgado Benito \& Casado Muñoz, 2013). Challenges of online learning increases in academic staff time (Allen et al., 2013; Ramsden, 2003), changes in the distribution between tasks; the problem of changes in the proportion of support staff needed; and the initially high 
costs of adaptive systems. Minimum standards for the quality of online learning are the stability of the technology, demonstrated coherence with other parts of the curriculum, clearly defined expectations about access to teachers, and integrated monitoring of the student experience (Ramsden, 2003).

In line with the challenges in a changing educational landscape, students' ability to adapt concerns the most. While educational institutions can perhaps immediately prepare for the paradigm shift towards online delivery of learning, students cannot. With this in mind, data from the Organization for Economic Cooperation and Development (OECD) revealed contrasting situations whilst $95 \%$ of students in Switzerland, Norway, and Austria have a computer to use for their schoolwork, only 34\% in Indonesia do (WEF, 2020). In other words, 5\% of the students in progressive countries of Switzerland, Norway, Austria, and $66 \%$ in Indonesia did not have computers for their schoolwork. While in Kajeet (2020), 14\% of students, or 14 million students across America, do not have internet access at home.

Moreover, the protection of children and educational facilities were particularly important. Precautions are necessary to prevent the potential spread of COVID-19 in school settings. Likewise, exercise care not to stigmatize students and staff exposed to the virus (Tsaranov, Zhiltsov, Klimova \& Tarbastaev, 2020; UNICEF, 2020). The government and school authorities cannot just ignore these.

Subsequently, the broader impact of the coronavirus pandemic is on households due to the widespread loss of employment, e.g. from small businesses that cannot afford to retain employees, or informal workers in temporary jobs, gig economy workers, and from the services sector, especially travel, tourism, retail, and other services (ASEAN, 2020). These conditions significantly affect the financial capabilities of parents/guardians to send their children back to school for the SY 2020-2021.

\section{Results and Discussion}

\subsection{Sources of Income of Parents of Maritime Students}

Results in Table 1 showed that there were more parents having an informal income source. Far second, third, and fourth were government, private, and OFW groups, respectively. It was necessary to determine the income sources of the parents of the maritime students to know how financially ready they are for the start of SY 2020-2021. Without measuring this is negligent and may result in weak decision making on the part of the school administration.

Table 1. Income source of parents

\begin{tabular}{lcc}
\hline & Frequency $(\mathrm{n}=271)$ & $\%$ \\
\hline Government & 71 & 26.20 \\
Private & 32 & 11.81 \\
Overseas Filipino Workers (OFW) & 20 & 7.38 \\
Informal & 148 & 54.61 \\
\hline
\end{tabular}

Results show that $54.61 \%$ of the parents have an informal income source. Parents in this income group do not have a regular income. According to the International Labour Organization [ILO] (2020), labor laws, and regulations of the country do not cover workers in this sector. The result implied that families in this source income group were the most economically affected this time of the COVID-19 pandemic. The government's implementation of calibrated lockdowns to prevent the spread of the virus aggravated the economic difficulties of the families. Suddenly, almost everybody in this group lost their opportunities to earn a living.

On the other hand, $26.20 \%$ of the parents sourced their income from government employment. Government employees were receiving low salaries and wages. While $11.81 \%$ of parents have their income from private employment, especially those working with small private enterprises whose financial resources were limited. In addition, 7.38\% of the parents have their source of income from overseas employment as OFW. Many OFWs lost their jobs due to untimely repatriations caused by the COVID-19 pandemic.

Results implied that there exists wide inequality of income sources among the parents of maritime students. Regardless of the income source group, the economic impact of the COVID-19 pandemic has affected all the maritime students' parents. All of them were vulnerable to the economic recession characterized by a long period of community lockdowns and losing opportunities to earn a living. Thus, everybody was in the survival mode triggered by the COVID-19 pandemic. This suggests uncertainties among maritime students in terms of financial capabilities in pursuing their maritime studies for the SY 2020-2021. 


\subsection{Intent to Pursue Schooling}

The majority of the maritime students were from geographically dispersed places in Eastern Visayas and neighboring provinces. This meant that maritime students have to stay away from their respective homes for them to study maritime education. Subsequently, due to the spread of the coronavirus, these maritime students were in their respective homes at present due to the community lockdowns. Thus, things would be different this time especially in terms of pursuing their studies.

Table 2 revealed that $79.70 \%$ intend to pursue their studies for the SY 2020-2021. This implied that a majority of these maritime students were unaffected despite the impact of the COVID-19 pandemic as regards to their plans in acquiring a degree.

Table 2. Intent to pursue maritime studies

\begin{tabular}{lcc}
\hline & Frequency $(\mathrm{n}=271)$ & $\%$ \\
\hline Yes & 216 & 79.70 \\
No & 4 & 1.50 \\
Unsure & 51 & 18.80
\end{tabular}

On the other hand, barely $1.5 \%$ responded 'no' and $18.80 \%$ were 'unsure' in pursuing their studies for the SY 2020-2021. Inasmuch as these were both considered a reduction, the combined result of $20.30 \%$ or 1 of 5 has no intention in pursuing their studies for the same school year. Combining the two options would make the school extra cautious in dealing with any future uncertainties resulting from the reduced student population outcomes. The results were consistent with the monitoring report of ICEF (2020) highlighting the financial impact the pandemic is having on higher education, and if the pandemic continues for a quarter it could have severe short and long-term consequences, including declining student enrollment and a decrease in the collection of tuition fees (UNAI, 2020; ICEF, 2020).

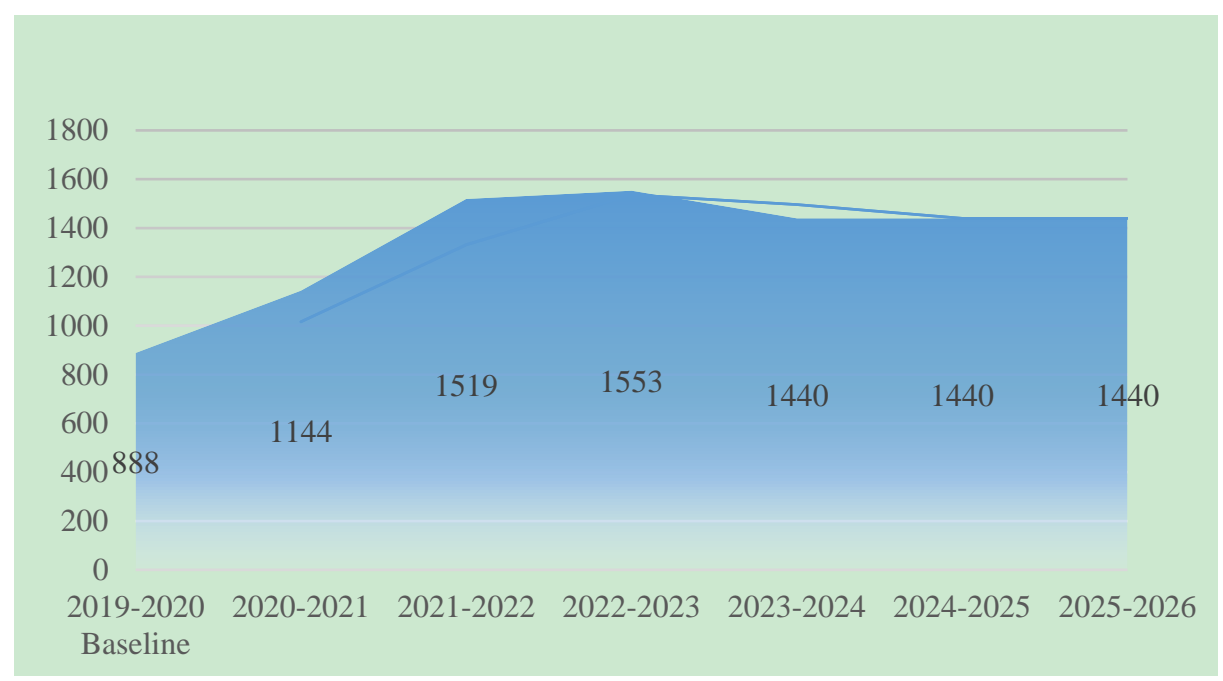

Figure 2. Students' population scenarios from SY 2020-2021 up to 2025-2026

Table 2 and Figure 2 show the students' population scenarios for the SY 2020-2021. A reduction ranging from 136 to 224 maritime students will likely happen from the start until the end of the school year. This despite the free tuition already enjoyed by these maritime students. This reduction outcome is attributable to the economic recession impact of the COVID-19 pandemic. Because of the economic difficulties, the likelihood of dropping from school throughout the school year is likely to occur. This may result in a domino effect in the upcoming SY 2021-2022, 2022-2023, and possibly 2023-2024 in terms of faculty requirements, classrooms and laboratories, simulator facilities, learning materials, and deployment of cadets, among others.

On the other hand, there would be 79 and 113 (Figure 2) more maritime students for the SY 2021-2022 and 2022-2023, respectively. This is in excess of the MHEIs approved carrying capacity of 1.440 per academic year. This is due to the influx of returning maritime students who did not pursue schooling in the previous SY 2020-2021. 
However, the scenario will normalize starting the SY 2023-2024 onwards as the student population curve flattens (Figure 2).

Moreover, as shown in Table 2, the number of maritime students who did not pursue in the upcoming school year has implications in the deployment of cadets by the end of SY 2020-2021. This would result in the shortage in the deployment of cadets for onboard training, either international or domestic.

Although, the situations in the SY 2021-2022, 2022-2023, and possibly 2023-2024 will be different, the possibility of having excess cadets available for onboard training deployment would likely to happen. These numbers could be above the actual requirements by the shipping companies. Surplus of available cadets will become a challenge to the MHEIs in terms of deployment of cadets for onboard training.

\subsection{Readiness in Coping the Abrupt Paradigm Shift to Online Learning}

Results in Table 3 revealed the readiness of the maritime students in coping with the abrupt paradigm shift to online learning. One of the factors asked was about personal wellbeing during this time of the pandemic (Tsaranov et al., 2020; UNAI, 2020; UNICEF, 2020). Results showed the perception of $74.54 \%$ of the maritime students that they were not personally well. This implied that the sudden lockdowns and quarantines due to the COVID-19 pandemic forced them to be socially isolated from their classmates, peers, friends, and relatives. This suggests that school authorities should look into their personal wellbeing too.

Table 3. Readiness in coping the abrupt paradigm shift

\begin{tabular}{lcc}
\hline & Yes (\%) & No (\%) \\
\hline Perception on personal wellbeing & 25.46 & 74.54 \\
Own a computer/laptop & 26.20 & 73.80 \\
Internet connection at home & 44.65 & 55.35 \\
Access to internet-shop & 20.30 & 79.70 \\
Overall & 29.15 & 70.85 \\
\hline
\end{tabular}

As regards ownership of a computer or laptop for schoolwork purposes, Table 3 shows $73.80 \%$ of maritime students did not have such gadgets. In the same breadth, $66 \%$ of students in Indonesia and among the 15 -year-olds in the US, nearly $25 \%$ of disadvantaged backgrounds did not have a computer to work on (WEF, 2020). This result implied that transitioning to online learning or blended learning would leave behind a huge majority of maritime students.

In terms of having an internet connection at home, Table 3 showed $55.35 \%$ did not have a connection. In the same breadth, 14\% of students or 14 million students across America did not have internet access at home (Kajeet, 2020). The result implied difficulties for the students to shift to online learning. Without an internet connection at home, the situation is not supportive of transitioning to the new delivery of learning. On the other hand, as regards whether the maritime students have access to an internet shop, Table 3 shows $79.70 \%$ did not have access. This has aggravated the difficulties in shifting to online learning, as students need to go out of their homes every time they will attend online classes.

In the analysis as regards to the maritime students' readiness in coping with the paradigm shift to online learning, Table 3 shows $70.85 \%$ were not ready for it. The implied challenges (Ramsden, 2003) for the maritime students to deal with adapting the system as part of the new normal. Whether the end-logic of these developments spells the creative destruction (Christensen \& Erying, 2011) or transformation (Barber et al., 2013) of maritime education, taking the due course now should be logical and factual. Results suggest wide inequalities among maritime students as regards coping with the abrupt paradigm shift of learning this time of the coronavirus COVID-19 pandemic.

\subsection{Delivery of Learning}

Results in Table 4 revealed how diverse the choices in the application of the delivery of learning are in the upcoming school year. The impact of COVID-19 pandemic on maritime education in this part of the country was significant and game-changing. The paradigm shift to the use of online learning was even complicated due to the demographic origin of these students who were spread all over the region. 
Table 4. Preference in the delivery of learning

\begin{tabular}{lcc}
\hline & Frequency & $\%$ \\
\hline Online Learning & 57 & 21.03 \\
Blended Learning & 62 & 22.88 \\
Face-to-Face Learning & 152 & 56.09
\end{tabular}

Of the three options in the delivery of learning, $56.09 \%$ of the maritime students preferred most the traditional or face-to-face learning. The learning process will be real and interactive. Despite the present threat to human health and safety due to the novel coronavirus COVID-19 pandemic, a sizable number of students still opted for the traditional way of learning.

On the other hand, barely $21.03 \%$ and $22.88 \%$ of the maritime students have preferred online and blended learning, respectively. Both online and blended need a 24-hour, 7 days a week internet connectivity at home and a computer. For internet-based learning, according to Stern, (n.d.), a computer, 24/7 internet connectivity and motivation were minimum requirements. This would pose a huge challenge to maritime students.

In the Philippines, abruptly shifting to online learning implied challenges to the students and to the country's entire educational system. Exacerbating these challenges is the internet speed in the country. Based on the 2015 data, the country has a meager internet speed of $2.8 \mathrm{Mbps}$, which placed the country in 104th among 160 countries (Salac \& Kim, 2016). With a slow internet speed, shifting to online learning this time is courting failures.

\subsection{Concerns of the Maritime Students}

Concerns of the maritime students shown in Table 5 were grouped according to the theme. Seven identified primary themes serve as major barriers in coping with the paradigm shift. These concerns were derived from those offered by the respondents in this study.

Table 5. Concerns of maritime students

Concerns According to Themes

Reasons

Computer or Laptop for schoolworks

Smartphone

Internet connection

Internet speed

Data connection

Subjects requiring simulator equipment

Financial
Many of the maritime students did not own a computer or laptop for schoolworks. Without computer or laptop makes shifting to online learning very difficult for maritime students. Buying a computer or laptop this time would be difficult because of the economic recession caused by the COVID-19 pandemic.

Most of the maritime students have smartphones. Unstable data connection and limited storage capacity of smartphones will make them nt appropriate for online learning purposes.

Lack of internet connection at home. Internet connection at home is necessary to enable maritime students to shift to online learning. The installation of internet connectivity at home is very expensive. Most parents cannot afford this under the present economic recession.

Internet speed in the country is very slow and unstable. This is not supportive with the paradigm shift of online learning. Learning experiences through online learning would be very stressful both instructors and maritime students.

The data connection is weak and unstable all over Region 8. This is not supportive of online learning.

Face-to-face learning was most preferred by maritime students for subjects requiring simulator equipment like Navigation 6 - ECDIS (Electronic Chart Display

Information System), Navigation 5A \& 5B - Radar/ARPA, Marcom 1 \& 2 - Global

Maritime Distress and Safety System (GMDSS), and Automation, etc. Acquistion of competencies in subjects requiring the use of simulator would not possible through online learning.

Economic recession due to COVID-19 pandemic puts parents of maritime students in a survival mode. 
The economic impact of COVID-19 pandemic to parents of these maritime students is largely a mitigating factor for these students who are not able to cope with the shifting from face-to-face learning to online learning or blended learning. Understandably, this paradigm shift has financial implications as everybody was in survival mode due to the economic recession caused by the coronavirus. Thus, it would be very difficult for the parents to provide their students with the necessary computer or laptop, a new internet connection at home, and sustain internet connectivity charges, among others.

Another concern that is very common throughout the country is the internet speed. It is very slow and unstable. This implied that the country's internet infrastructures could not really support the shifting to online learning or blended learning. With a very slow internet speed, learning would become very stressful for every maritime student.

Moreover, in the maritime educational landscape of the Philippines, simulator equipment was extensively used to ensure the transfer of competences as per Standards of Training, Certification, and Watchkeeping 1978 (STCW '78), as amended, to maritime students. Maritime students were concerned about how they are able to use various simulator equipment when delivery of learning is through online learning. This concern is not exclusive to them, this is also true to faculty handling simulator-based subjects like Electronic Chart Display Information System (ECDIS), Radio Detection and Ranging/Automatic Radar Plotting Aid (Radar/ARPA), Global Maritime Distress and Safety System (GMDSS), and Automation, among others.

The overall implications derived from the thematic concerns of the maritime students are their difficulties or inabilities to cope with the paradigm shift in online learning this upcoming SY 2020-2021. This is a challenge of the government and school administrations they should not ignore.

\subsection{Alternative Action}

Figure 3 shows the "Catch-up Framework in Maritime Education" for the SY 2020-2021, 2021-2022, and 2022-2023 developed amidst the outbreak of COVID-19 pandemic. A catch-up helps students inclusively acquire education under varying conditions especially during emergencies (Nicolai, 2003; Sinclair, 2001). The framework is applicable to all maritime and non-maritime schools in the Philippines during this time of the pandemic.

This framework was in response to the demands of the changing educational landscape due to the pandemic and other emergencies caused by nature and or humanity. It was developed responding to the abrupt paradigm shift in the delivery of learning in maritime education by delaying the start of the school year 2020-2021 to January 2021.

This addresses the issue that not everybody is ready for the start of SY 2020-2021 by August or September 2020. The plan specifically provides an adaptation period of one semester, e.g. first semester of SY 2020-2021. This allows the school, faculty members, parents, and students to adapt to the changing educational landscape and prepare them in coping with the paradigm shift to online learning in maritime education. The adaptation period is very important especially on the part of the maritime students and their parents to put them in perspectives within the context of the new normal where COVID-19 continues to be a threat to the safety and health aspects of societies.

Classes for all $1^{\text {st }}$-year, $2^{\text {nd }}$-year, and $3^{\text {rd }}$-year maritime students for the 1st semester, SY 2020-2021 will start in January 2021. Figure 3 shows the number of semester/summer terms devoted for each year level until the completion of classroom instruction, thence the required 1-year onboard training. For the 3rd-year, the school year will start in November 2020. By following the catch-up framework, maritime students shall graduate within the prescribed period according to their respective curriculum year. Not included in this program is the 4th year maritime students because they are having their 1-year onboard training by this time.

The benefit of having this catch-up initiative is to prevent catastrophic failures in pushing the start of SY 2020-2021 hastily in August or September 2020. Happening together with it is the abrupt implementation of online learning without comprehensive planning and preparations. The catch-up framework will not compromise maritime students' opportunities to complete or graduate within the prescribed period of their curriculum year. More planning and preparations towards the implementation of online learning will make this paradigm shift more meaningful and motivating to the maritime students, in particular. 


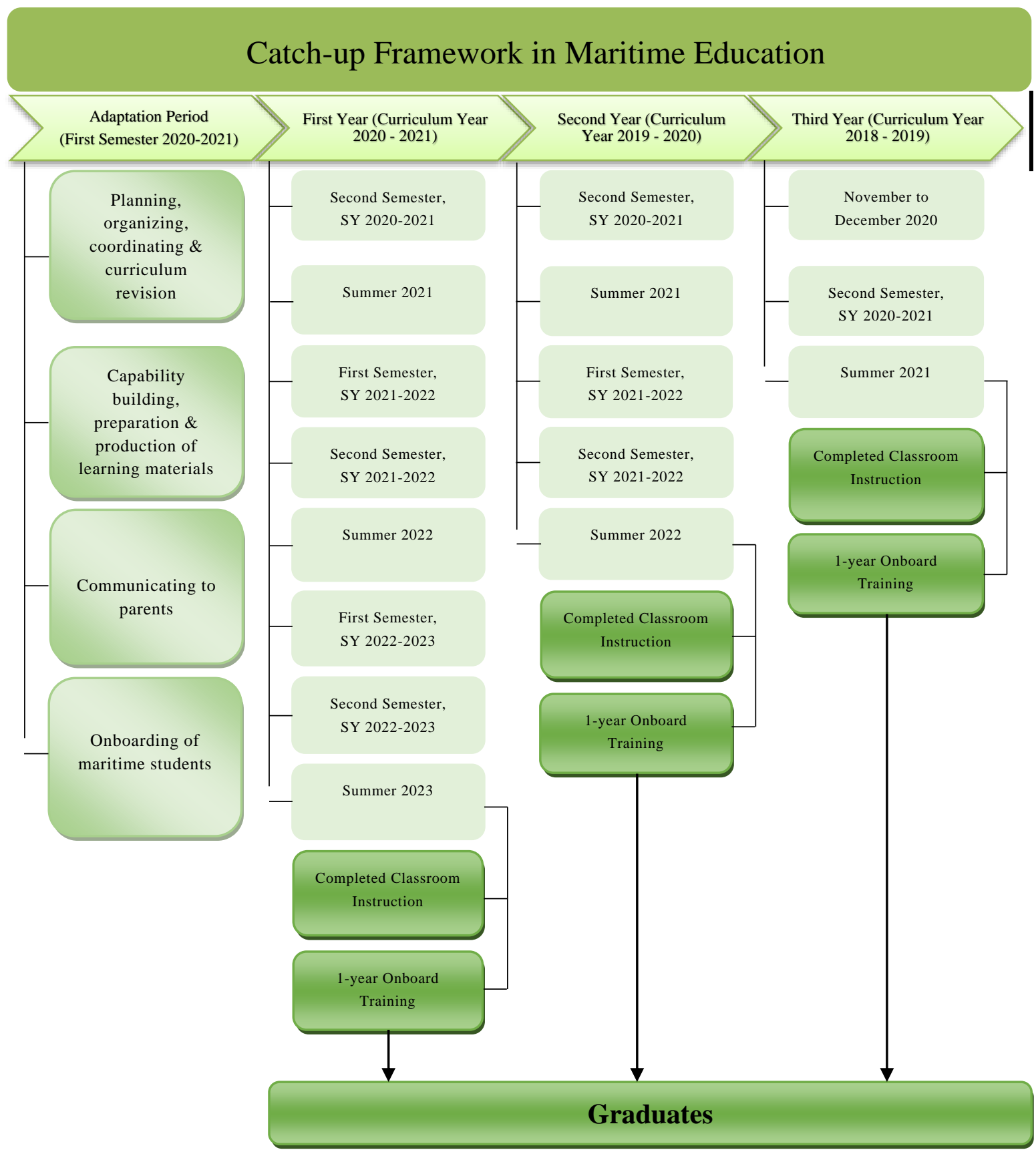

Figure 3. Catch-up framework in maritime education

The complete processes within the adaptation period of the catch-up framework shown in Figure 3 includes, but are not limited to:

1. Revision of curriculum. Categorization of all the subjects to lecture-based and laboratory-based.

1.1 Lecture-based subjects are the ones offered in the early part of the revised curriculum year. These subjects are deliverable through online learning or perhaps blended learning, as deemed appropriate. These subjects are pure knowledge-based. Maritime students would not find it difficult to acquire learning online.

1.2 Laboratory-based subjects, whether requiring simulator equipment or not, these could be offered at the later part of the curriculum years by face-to-face learning. Face-to-face learning, under a controlled learning environment, could be possible a year from now. In this strategy, acquisition of learning, skills, and competencies among maritime students would be probable. This ensures students 
the opportunities to have practical learning experiences in the operation of simulator equipment. In operating the simulator, students can simulate real-life navigational scenarios to develop the competencies expected from them.

2. Preparation of the catch-up program. Health and safety protocols would remain effective around the campus and inside classrooms and laboratory facilities. To minimize person-to-person contact, implement the ratio 1 to 15 for instructor-students and 1 to 1 for student-equipment until everything returns to normal.

The preparation would be according to the following:

2.1 Lecture-based subjects - using online learning model or perhaps blended learning, as follows:

2.1.1 First-Year level (Curriculum Year 2020-2021) - offering starts from the Second Semester SY 2020-2021 until Summer of 2022.

2.1.2 Second-Year level (Curriculum Year 2019-2020) - offering starts from Second Semester SY 2020-2021 until Summer of 2021.

2.1.3 Third-Year level (Curriculum Year 2018-2019) - catch-up period starts from November to December 2020.

2.2 Laboratory-based subjects - through face-to-face learning, whether requiring a simulator or not, under a controlled learning environment guided with strict health and safety protocols, as follows:

2.2.1 First-Year level (Curriculum Year 2020-2021) - offering starts from the First Semester SY 2022-2023 until Summer of 2023.

2.2.2 Second-Year level (Curriculum Year 2019-2020) - offering starts from First Semester SY 2021-2022 until Summer of 2022.

2.2.3 Third-Year level (Curriculum Year 2018-2019) - catch-up period starts from Second Semester SY 2020-2021 until Summer of 2021.

3. Presentation of the catch-up program for approval by the Academic Council and Administrative Council.

4. Secure approval from the Board of Trustees (BOT) or Board of Regents (BOR) for the catch-up program.

5. Submit to the Commission on Higher Education (CHED) the BOT or BOR approval for review and notation.

5. Conduct capacity-building activities to prepare all faculty members, department chairs, college dean, and office and technical staff, among others for the eventual transition to online learning.

7. Improve internet infrastructure in order to increase the present slow internet speed around the school. Internet speed is a factor for a successful internet-based learning model. The faster the internet speed the school has, the good results are highly achievable.

8. Communicate to all parents of maritime students specifically informing them of the eventual transition to internet-based learning suggesting them to provide their students with a computer/laptop and internet connectivity at home to enable them to cope with the paradigm shift.

9. Conduct orientation sessions with the maritime students before the start of the online-based classes to make them aware of how to navigate with the learning platform the school may use.

10. Better and comprehensive planning, preparations, coordinating, among others, make this paradigm shift achievable and successful. Make all systems go for the paradigm shift. This is so when the school, teaching staff, parents, and maritime students are all ready for it.

\section{Conclusion and Recommendations}

\subsection{Conclusion}

The impact of the coronavirus COVID-19 pandemic in the educational systems worldwide did not exempt the maritime education in the Philippines. All the MHEIs in the country are in a dilemma especially as regards to maintaining quality maritime education amidst the outbreak of the coronavirus COVID-19 pandemic.

Following the model shown in Figure 1, in the context of the Philippines maritime educational landscape, a maritime school cannot proceed with the abrupt paradigm shift in the delivery of learning from the face-to-face to online learning without the students' maximum participation. Students' participation at all times is an integral component of any educational institutions' success. Disregarding them would be crucial. Moving forward with online learning, this 
time of the pandemic is a great start, however tricky. Comprehensive planning and preparations are keys to successfully transition to online learning.

Pieces of evidence suggest that the maritime students, together with their parents, were not ready for the abrupt paradigm shift in time for the start of the school year 2020-2021. The economic impact caused by the novel coronavirus COVID-19 pandemic has affected the parents of the maritime students. Such economic difficulties aggravated the inabilities of these parents to sustain the maritime education pursuit of their respective students. The majority of the maritime students lack the necessary structural and financial supports to enable them to go with online learning. These present conditions strongly suggest the inabilities to inclusively participate or cope with the paradigm shift by the maritime students. Pushing the paradigm shift for SY 2020-2021 in August or September 2020 is bad judgment characterized by failures of management and lack of foresight.

The trend is shifting to internet-based learning, e.g. online learning and blended learning. This has become a challenge for MHEIs, either privately-funded or government-funded on how to do it instantaneously. Abrupt shifting to online learning is a nightmare to faculty and students intellectually, economically, and systematically. Anything hastily done without prior planning and preparation is a failure from the very start. In a maritime jargon, it is like sailing a ship in uncharted seas. When the direction is unclear, no specific action to take, and not ready to face to everything that might come on the way, catastrophic failure is most likely to happen instead of success.

Finally, the study has developed a catch-up framework in maritime education (Figure 3 ) to give everybody in maritime education extra time to cope with the paradigm shift to online learning amidst the pandemic. This suggests delaying the start of SY 2020-2021 to January 2021 instead. This catch-up framework will give every student equal and inclusive opportunities for education. It also allows them to graduate within the prescribed period based on their curriculum year.

\subsection{Recommendations}

1. Postpone the start of the upcoming school year 2020-2021 to January 2021. This is to give both students and parents sufficient time to cope with the changing educational landscape and prepare themselves in shifting to online learning. This is also extra time for MHEIs and teaching staff to prepare their learning materials, improve internet infrastructure, and setting-up of learning platforms, among others.

2. Adapt and implement the developed catch-up framework for SY 2020-2021, 2021-2022, and 2022-2023. The framework shows the maximization of time without compromising quality and not delaying maritime students' year of completion of classroom instruction, 1-year onboard training, and graduation. However, 3rd-year maritime students should start their school year in October 2020.

3. In implementing the framework, it is prudent for the school to prepare a contingency plan in the event the government will allow the resumption of face-to-face learning by January 2021. In such a situation, the formulation of safety and health protocols inside the school premises is a must to ensure that everybody is safe from COVID-19 pandemic is necessary.

4. Evaluate the effectiveness of the catch-up framework starting at the end of the Third Year (Curriculum Year 2018-2019) in summer 2021, then, summer 2022 for Second Year (Curriculum Year 2019-2020), and summer 2023 for First Year (Curriculum Year 2020-2021).

5. Gradually introduce the application of eLearning materials like the augmented reality (AR) and virtual reality (VR) which maritime students can both use online or offline.

6. When everything returns to normal, continue integrating the minimum use of internet-based delivery of learning in maritime education. Gradual integration is much better than abrupt shifting.

7. When implementing online learning, complement it with the distribution of printed learning materials to maritime students such as workbooks and work texts.

8. Starting the SY 2021-2022, require all incoming maritime students to have a computer or laptop of their own for school works. What happened during this time of the pandemic is a wake-up call to everybody in the academic communities.

\section{References}

Ahmed, H., Allaf, M., \& Elghazaly, H. (2020). COVID-19 and medical education. https://pubmed.ncbi.nlm.nih.gov/32213335/. https://doi.org/10.1016/S1473-3099(20)30226-7

Allen, I.E., \& Seaman, J. (2013). Changing course: ten years of tracking online education in the United States. https://files.eric.ed.gov/fulltext/ED541571.pdf. 
Association of Southeast Asian Nations. (2020). Economic impact of COVID-19 outbreak on ASEAN. ASEAN Policy Brief, April 2020. https://asean.org/?static_post=asean-policy-brief

Baker, S., Bloom, N., Davis, S., \& Terry, S. (2020). COVID-induced economic uncertainty and its consequences. Retrieved August 22, 2020, from https://doi.org/10.3386/w26983

Barber, M., Donnelly, K., \& Rizvi, S. (2013). An avalanche is coming: higher education and the revolution ahead. https://doi.org/10.17323/1814-9545-2013-3-152-229

Biggs, J., \& Tang, C. (2011). Teaching for quality learning at university (4th edition). Poen University Press, McGraw-Hill Education, McGraw-Hill House, Shoppenhangers Road, Maidenhead, Berkshire, England SL6 2QL.

Brenton, S. (2015). Chapter 10 Effective online teaching and learning in Fry, H., Ketteridge, S. and Marshall, S. (Ed.), A handbook for teaching and learning in higher education enhancing academic practice fourth edition, RoutledgeFalmer, 2 Park Square, Milton Park, Abingdon, Oxon, OX14 4RN, pp.139-151.

Christensen, C., \& Eyring, H. (2011). The innovative university: changing the DNA of higher education from the inside

out. https://pdfs.semanticscholar.org/d1d4/7673cd04ad1add857e5cd17a69f51cc52644.pdf?_ga=2.22622075.613562 168.1594003325-728349242.1594003325

Delgado Benito, V., \& Casado Muñoz, R. (2013). GOOGLE docs: a collaborative work experience at the university. https://doaj.org/article/1d11dc2084dc4c1b8665066a849150dc

De Stefani, A., Bruno, G., Mutinelli, S., \& Gracco, A. (2020). COVID-19 outbreak perception in Italian dentists. Int. J. Environ. Res. Public Health 2020, 17(11), 3867. https://doi.org/10.3390/ijerph17113867

Dessel, G. V. (2013). How to determine population and survey sample size? https://www.checkmarket.com/blog/how-to-estimate-your-population-and-survey-sample-size/.

Fry, H., Ketteridge, S., \& Marshall, S. (2015). A handbook for teaching and learning in higher education enhancing academic practice (Fourth Edition). RoutledgeFalmer, 2 Park Square, Milton Park, Abingdon, Oxon, OX14 $4 \mathrm{RN}$.

Goh, P. S. (2016). Learning or technology enhanced learning in medical education - hope, not hype. Medical Teacher, 38(9). https:///doi.org/10.3109/0142159X.2016.1147538

Goh, P. S., \& Sandars, J. (2020). A vision of the use of technology in medical education after the COVID-19 pandemic. https://doi.org/10.15694/mep.2020.000049.1

Hilmi, M.F. (2016). Disruptive innovation in education: open learning, online learning, MOOCs and what next? https://www.semanticscholar.org/paper/Disruptive-Innovation-in-Education\%3A-Open-Learning\%2C-Hilmi/9d 7a4502ea2960c6ac62607284cc4130857592c6\#paper-header

ICEF. (2020). Measuring COVID-19's impact on higher education. 15 Apr 2020. https://monitor.icef.com/2020/04/measuring-covid-19s-impact-on-higher-education/.

International Labour Organization. (2020). Informal economy in the Philippines. https://www.ilo.org/manila/areasofwork/informal-economy/lang--en/index.htm.

Iwai, Y. (2020). Online learning during the COVID-19 pandemic: what do we gain and what do we lose when classrooms go virtual?

https://blogs.scientificamerican.com/observations/online-learning-during-the-covid-19-pandemic/

Jhaveri, K.D., Schrier, P.B., \& Joseph M.J. (2013). Paging doctor Google! heuristics vs. technology. https://doi.org/10.12688/f1000research.2-90.v1.

Kajeet (2020). Challenges to distance learning during the COVID-19 outbreak and tips to overcome them. https://www.kajeet.net/extracurricular/tips-to-overcome-challenges-to-distance-learning-during-covid19

Murphy, B. (2020). COVID-19: how the virus is impacting medical schools. https://www.ama-assn.org/delivering-care/public-health/covid-19-how-virus-impacting-medical-schools

National Economic Development Authority (2020). Addressing the social and economic impact of the COVID-19 pandemic.

https://www.neda.gov.ph/wp-content/uploads/2020/03/NEDA_Addressing-the-Social-and-Economic-Impact-of -the-COVID-19-Pandemic.pdf 
Nicolai, S. (2003). Education in Emergencies: a tool kit for starting and managing education in emergencies. Save the Children, 17 Grove Lane, London SE5 8RD, UK. https://resourcecentre.savethechildren.net/library/education-emergencies-tool-kit-starting-and-managing-educati on-emergencies.

Pike, N. (2015). Chapter 15 Experimental sciences. in Fry, H., Ketteridge, S. and Marshall, S. (Ed.), A handbook for teaching and learning in higher education enhancing academic practice fourth edition, RoutledgeFalmer, 2 Park Square, Milton Park,Abingdon, Oxon, OX14 4RN, pp.211-227.

Podik, I. I. (2017). The implementation of Google services for teaching generation Z students. Research Institute of Fiscal Policy at the University of the State Fiscal Service of Ukraine, Irpin. https://doi.org/10.33407/itlt.v60i4.1770.

Ramsden, P. (2003). Learning to teach in higher education (2nd edition). RoutledgeFalmer, 2 Park Square, Milton Park, Abingdon, Oxon, OX14 4RN.

Salac, R. A., \& Kim, Y. S. (2016). A study on the internet connectivity in the Philippines. https://doi.org/10.20522/APJBR.2016.1.1.67

Sinclair, M. (2001). Education in emencies. https://www.researchgate.net/publication/44827068_Education_in_emergencies

Sniazhko, S. (2019). Uncertainty in decision-making: A review of the international business literature. https://doi.org/10.1080/23311975.2019.1650692

Stern, J. (n.d.). Introduction to online and learning. http://www.wlac.edu/online/documents/otl.pdf.

Sukhwant, J. (2017). Rethinking higher education: a case study of institutional transformation. https://www.semanticscholar.org/paper/Rethinking-Higher-Education\%3A-A-Case-Study-of-Jhaj/345091959cd fadd06f1286663d52b98f0687d71f

Tsaranov, K.N., Zhiltsov, V.A, Klimova, E.M., \& Tarbastaev, A.G. (2020). Perceptions of personal safetyhazards in the context of the COVID-19 pandemic by USA and Russian medial staff. https://doi.org/10.18384/2224-0209-2020-2-1008

United Nations Academic Impact. (2020). COVID-19 and higher education: learning to unlearn to create education for the future. United

Nations. https://academicimpact.un.org/content/covid-19-and-higher-education-learning-unlearn-create-education-future.

United Nations International Children's Emergency Fund. (2020). Key messages and actions for COVID-19 preventionand control in schools. March 2020. Retrieved June 10, 2020, from https://www.unicef.org/romania/documents/key-messages-and-actions-covid-19-prevention-and-control-schools

Raju, N.V. and Harinarayana, N.S. (2016). Online survey tools: A case study of Google Forms. https://www.researchgate.net/publication/326831738_Online_survey_tools_A_case_study_of_ Google_Forms.

World Economic Forum. (2020). The COVID-19 pandemic has changed education forever. This is how. https://www.weforum.org/agenda/2020/04/coronavirus-education-global-covid19-online-digital-learning/

Zio, E., \& Pedroni, N. (2013). Risk Analysis Literature Review of Methods for Representing Uncertainty. Retrieved August 22, 2020, from https://www.foncsi.org/en/publications/collections/industrial-safety-cahiers/literature-review-uncertainty-repres entation/CSI-uncertainty-representation.pdf.

Zulueta, F.M., \& Costales, N.E.B. (2003). Methods of research thesis-writing and applied statistics. National Book Store, Metro Manila.

Zweifach S.M., \& Triola M.M. (2019). Extended reality in medical education: driving adoption through provider-centered design. https://doi.org/10.1159/000498923.

\section{Copyrights}

Copyright for this article is retained by the author(s), with first publication rights granted to the journal.

This is an open-access article distributed under the terms and conditions of the Creative Commons Attribution license (http://creativecommons.org/licenses/by/4.0/). 